\title{
Social, economic and institutional study of purse seine fisheries based on the ecosystem approach in the Fishing Port of Kutaraja, Banda Aceh
}

\author{
Salmarika Salmarika ${ }^{1 *}$, Am Azbas Taurusman ${ }^{2 *}$, Sugeng Hari Wisudo² and Muhammad Irham $^{3,4}$ \\ ${ }^{1}$ Department of Fisheries Resources Utilization, Faculty of Marine and Fisheries, Universitas Syiah Kuala, 23111 Banda Aceh, \\ Indonesia \\ ${ }^{2}$ Department of Fisheries Resources Utilization, Faculty of Fisheries and Marine Science, IPB University, 16680 Bogor, Indonesia \\ ${ }^{3}$ Geographical Information Systems Laboratory, Faculty of Marine and Fisheries, Universitas Syiah Kuala, 23111 Banda Aceh, \\ Indonesia \\ ${ }^{4}$ Department of Marine Sciences, Faculty of Marine and Fisheries, Universitas Syiah Kuala, 23111 Banda Aceh, Indonesia.
}

\begin{abstract}
Purse seine is the most dominant fishing gear used by fishermen at the Fishing Port of Kutaraja. It affects increasing the number of fishing fleets and fishing efforts per year. The increase is considered to have a negative impact on fishers because it can trigger competition and conflict between fishers, violate the law, and even affect fishermen's income. This study aims to assess the status and formulate fisheries management actions regarding social, economic, and institutional aspects of fishing based on purse seines in the Fishing Port of Kutaraja. This research was conducted in 2018, and data were collected through a survey method by conducting in-depth interviews with several respondents and analyzed using the Flag Modelling technique. The results showed the composite value of the social domain was $91.66 \%$ in a 'very good' category, the economic domain was $33.33 \%$ in 'poor' condition, and the institutional domain was $67.66 \%$ in a 'good' shape. These results indicate that economic management actions need to be better pursued so that purse seine fisheries remain sustainable in accordance with social, economic, and institutional conditions by; (1) implement a profit-sharing system in accordance with applicable regulations; (2) strengthening good cooperation between stakeholders; (3) open dissemination of the importance of Panglima Laot customary rules; (4) improve supervision and law enforcement; (5) increase the synergy of regulations, institutions and stakeholder capacities.
\end{abstract}

\section{Introduction}

Aceh Province has one of the largest fishing ports as a fishery center, namely the Fishing Port of Kutaraja. Fishers conduct fishing activities in the Indian Ocean waters. The dominant fishing gear based on Kutaraja Ocean Fishing Port is purse seine with large pelagic fish and small pelagic fish [1]. Meanwhile, other fishing gears used by local fishermen are handlines and longlines. The number of purse seine fleets from 2013 to 2018 has increased in line with the increase in fishing effort per year. In 2014 the purse seine fishing fleet was 238 units and continued to increase until 2018 reaching 264 units [2].

The high number of purse seine fleets in the Fishing Port of Kutaraja causes decreasing the proportion of catch per vessel. This triggers fishers to increase their fishing intensity. As a result, there is competition among fishers to increase the catch as much as possible. Competition between fishers generally caused conflict and increases the number of lawlessness related to fishing activities. On the other hand, an increased fishing intensity impacts the abundance of catches in the Fishing Port of Kutaraja, and it will also affect the price of fish. This is supported by [3] that fish prices are influenced by the number of catches and other important factors in fish marketing. Based on these conditions, if the number of fish stocks is not proportional to the number of buyers, then the price of fish becomes unstable. The price of fish is an important factor in supporting the increase in fishermen's income.

The application of economic and social aspects of purse seine fishers is related to each other, so efforts are needed to keep these two aspects in balance. The balancing of economic and social's fishers cannot be separated from the role of stakeholders as managers. Furthermore, the success of fisheries management efforts is highly dependent on stakeholder's implication to participate and work actively towards the goals to be achieved [4]. Fisheries management is an effort to maintain the sustainability of fishery resources by considering aspects to related in an integrated, such as the ecosystem approach. The ecosystem approach aims to manage fisheries sustainability by balancing ecosystem well-being, human well-being, and harmonious governance. Based on the problem focus that exists in the Fishing Port of Kutaraja, the researchers are interested to research the management of

*Corresponding author: azbas@apps.ipb.ac.id 
purse seine fisheries based on the EAFM in terms of economic, social, and institutional aspects.

\section{Method}

\subsection{Site and Location}

This research was conducted in the Fishing Port of Kutaraja in Aceh Province from September to October 2018. The selection of Kutaraja Ocean Fishing Port as the research location was based on the consideration that the Fishing Port of Kutaraja is the largest fishing port and fish landing center in Aceh Province.

\subsection{Data Collection Methods}

Research data includes both primary and secondary data. The Primary data were obtained from the results of interviews with the distribution of questionnaires. Secondary data was collected from annual report data and documents related to the amount of Province minimum wage in Banda Aceh City, the percentage of loan interest rates, the number of fishermen conflicts, the customary rules documents, rules, or policies that apply in the community related to fisheries management.

Respondents were determined to use the purposive sampling technique. The sample of fishers was selected $25 \%$ of the total population [5]. Based on the references, the number of fishermen respondents were 65 respondents. The basic considerations for selecting a sample were the presence and availability as a respondent, reputation, position, and credibility as an expert, experiences, and knowledges related to the problems of the study [6]. Then, each one expert respondent represents a stakeholder consisting of the Aceh Provincial Marine and Fisheries Service, the Marine and Fishery Resources Supervision Unit, the Marine Police, Customary Institutions, and Academics.

\subsection{Data Analysis}

The data were analyzed descriptively and quantitatively to evaluate the existing condition of each indicator in the social, economic, and institutional domains. Data analysis consists of 2 stages, namely identifying and assessing each indicator.

\subsubsection{Indicator identification}

The fisherman's household income indicator was measured by the total income of fishermen during fishing activities and compared to the Provincial Minimum Wage from Aceh Province. The fisherman's savings ratio indicator serves to determine the potential of fishermen's households in saving their income as an indicator of the level of fishermen's welfare. The formula for saving ratio according to [7] is as follows:

$$
\text { Saving Ratio }=\frac{(\text { Income-Outcome })}{\text { Income }} \times 100 \%
$$

Stakeholder participation aims to determine the level of involvement in the management of the purse seine fishery. The failure of fisheries management can be seen in how often conflicts occur in waters. The more often fishers conflict occurs, the more it shows an imbalance in fisheries management so that conflict indicators become important. The indicator of local knowledge is one of the benchmarks for the level of effectiveness of fisheries management. The more local knowledge is applied in the community, the greater the chance of successful fisheries management. The local knowledge in question includes traditional ecological knowledge such as applicable customary laws.

Indicators of compliance level with the principles of responsible fisheries were measured by the frequency of violations by fishers, both formal and informal. The completeness of the rules was reviewed from the availability of policies related to fishing business licensing and fishing operations. The decision-making mechanism for fisheries management was seen by the decision-making procedures related to the rules for fisheries management. Furthermore, the fishery management plan was reviewed from its availability related to purse seine fisheries management. The synergy and capacity of stakeholders were measured by the number of policies and institutions that contribute.

\subsubsection{Indicator assessment}

The assessment of EAFM domains and indicators was conducted by Multi Criteria Analysis (MCA) approach with the development of a composite index using a Likers scale score (ordinal based 1, 2, and 3). Indicators in the ecosystem approach are used to assess fisheries management performance in a particular area [8]. The stages of indicator assessment are (1) identifying the criteria for each indicator; (2) assigning a score for each indicator (ordinal based 1,2,3); (3) determine the weight of each indicator; and (4) develop a composite index for each indicator. According to [7], the equation that can be used to calculate the index value of the indicator is as follows:

$$
\text { Index value }=\text { score } \mathrm{x} 100 \mathrm{x} \text { quality }
$$

The next step is to determine the composite score for each EAFM domain, which can be calculated using the following equation:

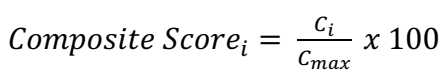

The composite value is visualized by the flag model in Table 2. The model describes the condition of fish resource management in the categories of 'bad', 'poor', 'moderate', 'good', and 'excellent' [7]. 
Tabel 1. Domain and aggregate value score limits

\begin{tabular}{|c|c|c|}
\hline Composite Score & Flag Model & Category \\
\hline $1-20$ & & Bad \\
\hline $21-40$ & & Poor \\
\hline $41-60$ & & Moderate \\
\hline $61-80$ & & Good \\
\hline $81-100$ & & Excellent \\
\hline
\end{tabular}

\section{Results and Discussion}

\subsection{Economic Domain}

The status of purse seine fisheries management from the economic domain is viewed from the fishermen's household income and saving ratio indicators. The composite value of the economic domain, which was 33.33, means that it is included in the poor category (Table 2). This economic condition is feared to be a problem that fisheries management cannot be optimal if the welfare of the actors has not been realized because one of the goals of fisheries management is to ensure human well-being.

Tabel 2. Economic domain composite assessment results

\begin{tabular}{|l|c|c|c|}
\hline \multicolumn{1}{|c|}{ Indikator } & Skor & Quality & $\begin{array}{c}\text { Index } \\
\text { value }\end{array}$ \\
\hline $\begin{array}{l}\text { Household income of } \\
\text { fishermen }\end{array}$ & 1 & 60 & 6000 \\
\hline Saving ratio & 1 & 40 & 4000 \\
\hline Total & & 100 & 10000 \\
\hline Domain maximal value & & & 30000 \\
\hline Domain composite value & & & 33.33 \\
\hline Category & & & Poor \\
\hline
\end{tabular}

Income is the result obtained from business activities in the form of money and goods that can meet the needs of life [9]. Fishermen's household income is one of the determining factors for the success of the fishing business. A source of fishermen's income was drawn from the sale of their catch. Information of fish price is very important, the price of fish gives an income overview that fishers get from their catches [10]. The higher the fish price, the higher the proportion of fishermen's income, but if the price of fish decreases, the proportion of fishermen's income will also decrease.

The difference in the profit-sharing system for purse seines affects the proportion of the income of each fisher. The division is adjusted to the job duties. The average income of purse seine fishers at the Cempae Soreang Fish Landing Base in Parepare City was around IDR 671,875 per month, while at the Ocean Bungus Fishery Port, Padang City around IDR 1,870,200 per trip $[11,12]$. Based on the results of the business analysis, the average household income of fishers was IDR $1,003,822$ per month. When compared with the Aceh Province Minimum Wage stipulated in Aceh Governor Regulation No.67/2017 concerning the 2018 Aceh Province Minimum Wage Determination, which was IDR 2,700,000 it can be concluded that the household income of the fishermen was very low. The low income of fishermen's households can impact the ability of fishers to meet their daily household needs.
The savings ratio of purse seine fishermen based in Kutaraja fishing port was -1.73 . If the savings ratio value is positive, the fisherman can increase their assets such as household appliances, electronics, but if it is negative, the crew tend not to be able to increase their total assets [13]. Based on the ratio of savings owned by purse seine fishermen, it shows that income as a fisherman has not been able to increase the ability to increase the number of household assets. Furthermore, the value of the fisherman's savings ratio was also very much smaller when compared to the prevailing loan interest rate at Bank Indonesia (10.81\%), so this further indicates that the income earned by fishermen has not been able to guarantee the welfare of the fishermen themselves. Meanwhile, human welfare can be realized from the sustainability of its ecological, social and economic systems [14].

\subsection{Social Domain}

The status of the social domain can be seen from stakeholder participation, fishermen's conflicts, and local knowledge related to fisheries management indicators. The composite value of the social domain obtained is 91.66 , which is interpreted that the social management of fisheries is included in the 'very good' category (Table 3). The research results by [15] in Banda Aceh also showed that the social domain was categorized in 'good' condition. This condition is very supportive to realize fisheries management can be run properly.

Stakeholder participation has been $100 \%$ conducted for the purse seine fishery management at Kutaraja Ocean Fishing Port. This percentage was seen by the participation of stakeholders in activities in the surrounding area related to fisheries management. Stakeholder participation is an important indicator as a reflection that management efforts can be carried out together by involving many parties. This type of management is often equated with joint fisheries management or co-management. Co-management is defined as joint fisheries management by involving stakeholders to formulate policies for the common interest [16]. Co-management is considered the main approach in implementing fisheries with an ecosystem approach [17]. Efforts to increase stakeholder participation for fisheries management must be carried out effectively to realize synergies between institutions and policies properly.

Conflicts between fishers based in the Kutaraja fishing port were less than two times per year. Based on data obtained from the traditional Panglima Laot institution, fishers conflicts occurred in 2015 due to FAD ownership claims and in 2017 there was a ship collision at the port dock. Conflicts are usually resolved with Panglima Laot by deliberation and are given sanctions according to applicable customary rules in the form of compensation, confiscation of catch, or prohibition from going to sea within a mutually determined period.

On the other hand, the principle of fisheries management is not only limited to scientific information but also obtained by utilizing the best available 
information. Information can be obtained from a combination of qualitative and quantitative data by utilizing various sources of knowledge, which is traditional knowledge or local wisdom [17]. Positive local wisdom values are recognized and maintained by the community, and can also play a role in environmental protection and management [18]. In Indonesia, there are several practices of customary rules, namely Awig-Awig in West Lombok, Mane'e in North Sulawesi, Sasi Laut in Maluku [19]. Aceh province also has a privilege that other regions do not have, namely the Panglima Laot institution. This institution has customary rules that have been passed down from generation to generation and are used by the local community as a guide for social life with others according to customs, customs, and religion. So far Panglima laot has carried out its role to manage fisheries well, especially in Banda Aceh City [20]. However, the implementation of these customary rules is not effective yet because some fishermen do not fully understand about customary law. The same thing also happened to fishermen in Sumbawa in grouper and snapper fisheries, they have not utilized local knowledge for fish resource management efforts [21]. As a result, it can reduce the essence of local knowledge itself.

Tabel 3. Social domain composite assessment results

\begin{tabular}{|l|c|c|c|}
\hline \multicolumn{1}{|c|}{ Indicators } & Skor & Quality & $\begin{array}{c}\text { Index } \\
\text { value }\end{array}$ \\
\hline $\begin{array}{l}\text { Stakeholder } \\
\text { participation }\end{array}$ & 3 & 40 & 12000 \\
\hline Fisherman conflict & 3 & 35 & 10500 \\
\hline $\begin{array}{l}\text { Local knowledge of } \\
\text { fisheries management }\end{array}$ & 2 & 25 & 5000 \\
\hline Total composite & & & 27500 \\
\hline Domain maximal value & & & 30000 \\
\hline $\begin{array}{l}\text { Domain } \\
\text { value }\end{array}$ & & & Excellent \\
\hline Category & &
\end{tabular}

\subsection{Institutional Domain}

The institutional domain consists of 6 indicators, namely the compliance level with the principles of responsible fisheries, the completeness of the rules, decision-making mechanisms, Fisheries Management Plans (FMP), the level of synergy between policies and institutions of fisheries management, and the capacity of stakeholders. The composite value for the institutional domain is 67.77 , which is included in the 'good' category (Table 4).

The level of compliance with the principles of responsible fisheries is related to legal norms in the Code of Conduct for Responsible Fisheries (CCRF). The frequency of formal violations committed by fishermen was 62 violations and 4 informal violations. The high level of violations indicates that the principles of good fishing business are difficult to implement, even though the government has implemented the rules well so far. The rules that have been applied at the Kutaraja fishing port include rules for the use of fishing gear, permits, as well as fishing areas and routes that are enforced following standards and sanctions for each violation. However, in practice, it has not been optimally implemented due to limited human resources.
On the other hand, the available rules of the game have not been able to be used as a reference in making fisheries management decisions. Because they often conflict with the habits that have been passed down from generation to generation by fishermen. So far, the government has legalized the fisheries management plan, especially for economically important fish such as Tuna, Skipjack, Bullet Tuna stated in KEPMEN KP No. $107 / 2015$. The FMP is related to purse seine fisheries because Tuna, Skipjack, Bullet Tuna are the targets of purse seines.

Tabel 4. Institutional domain composite assessment results

\begin{tabular}{|l|c|c|c|}
\hline \multicolumn{1}{|c|}{ Indicators Skor } & Quality & $\begin{array}{c}\text { Index } \\
\text { value }\end{array}$ \\
\hline $\begin{array}{l}\text { The compliance level with } \\
\text { the of } \\
\text { principles fisheries }\end{array}$ & 1.5 & 26 & 3900 \\
\hline $\begin{array}{l}\text { The completeness of the } \\
\text { rules }\end{array}$ & 2 & 25 & 5000 \\
\hline $\begin{array}{l}\text { Decision-making } \\
\text { mechanisms }\end{array}$ & 2 & 18 & 3600 \\
\hline $\begin{array}{l}\text { Fisheries management } \\
\text { plans }\end{array}$ & 2 & 15 & 3000 \\
\hline $\begin{array}{l}\text { The level of synergy } \\
\text { between policies and } \\
\text { institutions of fisheries } \\
\text { management }\end{array}$ & 3 & 11 & 3300 \\
\hline $\begin{array}{l}\text { The capacity } \\
\text { stakeholders }\end{array}$ & 3 & 5 & 1500 \\
\hline Total & & & 20300 \\
\hline Domain maximal value & & 30000 \\
\hline Domain composite value & & 67.66 \\
\hline Category Good \\
\hline
\end{tabular}

The synergy level between policies and institutions can be described through good cooperation. Based on interviews, the synergies built between stakeholders and policies do not overlap and support each other. The policies cover the level of customary institutions, districts, provinces, to the central government. This is because the harmonizing of governance and management systems is an important point that must be possessed for catalyzing fisheries management action successfully in various conditions [22]. In addition, efforts to increase the capacity of stakeholders are also continuously pursued by participating in activities that support the ability to implement fisheries management. This is a great opportunity for good fisheries management.

\subsection{Management Recommendations}

The assessment of the EAFM indicator in the economic domain shows an unfavorable condition (Table 2). Based on this value, it makes the economic domain a priority in the management of purse seines. The management action that needs to be taken is to implement a profit-sharing system by applicable regulations so that fishermen's income will ensure the welfare of fishers. A non-standard profit-sharing system can cause income inequality for fishers [23]. The ideal fishery product sharing should be implemented as stated in Law No. 16 of 1964 article 3, namely 60:40\%. Opinion by [24] that the ideal profit-sharing system for 
fishermen is $52: 48 \%$, which are $52 \%$ is for boat owners and $48 \%$ for the crew. This comparison hopefully can improve the living standard of the fishermen. Another solution is to socialize business management, provide capital and create alternative livelihoods for fishers $[25$, 26].

On the other hand, the management of the purse seine fishery from a social and institutional point of view has worked very well (Table 3 and 4). However, in its implementation, it still requires management actions to maintain this situation. Actions that need to be taken are strengthening good cooperation between stakeholders to increase synergies in managing fisheries together with co-management. Co-management can increase participation, communication, human resources, trust, and information between stakeholders and fishers [27]. Teamwork between stakeholders will also reflect efforts to prevent conflicts between fishers because conflicts are prone to occur between parties with different views. [28] also argues that conflict can start because of the inequality of one party with another. Cooperation is also helpful in improving law enforcement and supervision. So, it is essential to continue to increase cooperation.

Another management action is socialization regarding the importance of open Panglima Laot customary rules so that local knowledge can be useful for management, especially the purse seine fishery at the Kutaraja Ocean Fishing Port. Socialization can be done by re-notifying the points of the customary rules along with the sanctions and the benefits of implementing the rules themselves. Socialization can also be done through information media placed around the port so that its implementation can be more effective than holding a meeting because it takes into account the availability of fishermen's time.

\section{Conclusion}

This study concludes that the assessment of purse seine fishery through economic domain indicators was in the 'poor' category while the social and institutional domains were in excellent and good category. The actions of purse seine fisheries management that need to be focused on are implementing a profit-sharing system following applicable regulations, strengthening good cooperation between stakeholders, and publicizing the importance of open Panglima Laot customary rules.

\section{References}

1. Salmarika, A.A Taurusman, S.H Wisudo, Jurnal Penelitian Perikanan Indonesia 24, 263-272 (2018)

2. Syahbandar Perikanan Lampulo Fishing Port Data jumlah armada penangkapan di PPS Lampulo dari tahun 2013 sampai 2018 (Lampulo: Syahbandar Perikanan PPS Lampulo) (2018)

3. N. Zulbainarni Teori dan Praktik Permodelan Bioekonomi dalam Pengelolaan Perikanan Tangkap (Bogor: IPB Press) p 310 (2012)

4. I Muliawan, A. Fahrudin, A. Fauzi, M. Boer, J. Sosek KP 9, 233-246 (2014)
5. Food and Agriculture Organization Handbook for fisheries socioeconomic sample survey (Rome, FAO (Food and Agriculture Organization). (2017)

6. Edwarsyah and Gazali, Jurnal Perikanan Tropis 2, 37-43 (2015)

7. National Working Group on Ecosystem Approach to Fisheries Management Modul indikator pengelolaan perikanan dengan menggunakan pendekatan EAFM (Ecosystem Approach to Fisheries Management) (Jakarta, Direktorat Sumber Daya Ikan Kementerian Kelautan dan Perikanan Republik Indonesia) p 163. (2014)

8. M.R.S Damanik, M.R.K. Lubis, A.J.D. Astusi, Jurnal Geografi 8, 165-176 (2016)

9. Manggabarani and Ishak, Jurnal Agrovital 1, 27-33 (2016)

10. L. Richmond, D. Kotowicz, J. Hospital, Ocean and Coastal Management 106, 87-96 (2015)

11. F. Indahyani and Khairuddin, Jurnal Galung Tropika 5, 63-70 (2016)

12. W. Alan, Hendrik, F. Nugroho, JOM FAPERIKA 2 , 1-11 (2015)

13. D. J Tarigan Pengelolaan daerah penangkapan gurita (Octopus cyanea) secara berkelanjutan di Kabupaten Banggai Laut, provinsi Sulawesi Tengah [tesis] (Bogor, Institut Pertanian Bogor) (2018)

14. S. E. Rees, M. Ashley, L. Evans, S. Mangi, E. V. Sheehan, T. Mullier, A. Rees, M. J. Attrill, Fisheries Research 235, 1-10 (2021)

15. E Miswar, D. Natasya, M. Irham, R. M Aprilla, S. Agustina, J. M Affan, Analysis of social and economic aspects of management of marine and coastal resources based on EAFM (Ecosystem Approach to Fisheries Management) method in Banda Aceh City, in Proceedings of the International Conference on Fisheries, Aquatic and Environmental Sciences, ICFAES, 25-26 September 2018, Banda Aceh, Indonesia (2018)

16. R Indrawasih, J. Bijak dan Riset Sosek KP 3, 175198 (2008)

17. Food and Agriculture Organization Fisheries management: the ecosystem approach to fisheries, the human dimensions of the ecosystem approach to fisheries (Rome, FAO (Food and Agriculture Organization) (2009)

18. D. Oktaviani, E. Prianto, R. Puspasari, J. Kebijak. Perikan. Ind. 8, 1-12 (2016)

19. S. Oktaviyani, Oseana 40, 49-58 (2015)

20. A. Rahmah. S. Salmarika, E. Miswar, The role of panglima laot towards fisheries management based on ecosystem approach in Banda Aceh City, in Proceedings of the International and National Symposium on Aquatic Environment and Fisheries, INSAEF, 24 September 2020, Banda Aceh, Indonesia (2021)

21. S. Hilyana, S. Gigentika, M. T. Rafandi, Hernawati, Assesment of grouper and snapper fisheries with EAFM approach and sustainable strategy management in Sumbawa Indonesia, in Proceeding of the $3^{\text {rd }}$ International Conference on Bioscience 
and Biotechnology, 12-14 October 2020, West Nusa Tenggara, Indonesia (2020)

22. R. S. Pomeroy, L. R. Garces, M. D. Pido, J. E. Parks, G. Silvestre, Marine Policy 106, 1-10 (2019)

23. L. D Rejeki, S. Kasimin, T Fauzi, Jurnal Ilmiah Mahasiswa Pertanian Unsyiah 1, 520-531 (2016)

24. R. H. S. Tawari, D. Simbolon, A. Purbayanto, A. M. Taurusman, Buletin PSP 21, 237-245 (2013)

25. Ihsan, E. S. Wiyono, S. H. Wisudo, J. Haluan, J. Kebijak. Perikan. Ind. 7,25-36 (2015).

26. R. Widihastuti and L. Rosyidah, J. Kebijakan Sosek KP 8, 63-75 (2018)

27. M. Cucuzza, J.S. Stoll, H. M Leslie, Marine Policy 126, 1-10 (2021)

28. M.F.A Sondita 2010 Manajemen sumber daya perikanan (Jakarta, Universitas Terbuka). 